\title{
DIRECTOR AND EXECUTIVE REMUNERATION CLAWBACKS: A SUGGESTED APPROACH FOR SOUTH AFRICA
}

\author{
Vela Madlela \\ LLB LLM \\ Lecturer, Mercantile Law \\ University of South Africa (UNISA)
}

\begin{abstract}
SUMMARY
The purpose of this article is to explore clawbacks as a means of addressing problematic executive remuneration through an examination of the approaches adopted by the US, Australia, and certain European Union (EU) member states and to highlight the lessons that South Africa may draw from the experiences of these jurisdictions. The article first considers the intentions and assumptions of remuneration reforms, which have introduced clawbacks in these international jurisdictions. It then moves on to provide an overview of the US, Australian and EU clawback reforms, identifying and analysing the potential benefits and shortcomings of the regulatory reforms in each jurisdiction. The article asserts that the absence of a requirement for the clawback of incentive-based remuneration in South Africa is not in the interests of companies and their stakeholders since shareholders will have to institute often protracted and costly legal proceedings in order to recover erroneously awarded incentives. The article then makes recommendations on how remuneration clawbacks could be effectively incorporated into the South African regulatory framework.
\end{abstract}

\section{INTRODUCTION}

Excessive executive remuneration and perverse incentives continue to fuel debate amongst various company stakeholders in several jurisdictions. Corporate scandals and the global financial crisis of 2008-2009 raised widespread concern that inappropriate remuneration practices created unacceptable risk-taking in the financial institutions and incentivised the executives to focus on short-term gains instead of taking a long-term view. The developments underscored the need for effective regulatory interventions in order to restore confidence in the market, to ensure that the interests of company management are properly aligned with the long-term interests of the company and to discourage the rewarding of excessive risktaking.

1 Romano and Bhagat "Reforming Executive Compensation: Focusing and Committing to the Long-term" 2009 26(2) Yale Journal on Regulation 359 350-360. See also Murphy 
In an attempt to curb, problematic remuneration arrangements post the corporate scandals; certain international jurisdictions have introduced a variety of regulatory mechanisms, including subjecting the remuneration paid to certain directors and executives to a potential clawback. ${ }^{2}$ Performancebased incentives such as bonuses and share option schemes often constitute a substantial component of executive remuneration. ${ }^{3}$ The payment or vestings of these incentives are subject to the fulfilment of certain predetermined and measurable performance metrics. ${ }^{4}$ The mismeasurement of the performance metrics will clearly result in executives receiving erroneous incentives that are disproportionate to performance. This phenomenon is commonly referred to as "excess", "unearned", or "overpaid" remuneration. ${ }^{5}$ The corporate scandals have further highlighted that executives may potentially falsify the performance metrics in order to boost their performance-based incentives. ${ }^{6}$

Clawbacks allow companies to recoup excess or overpaid remuneration that has been erroneously awarded to directors and senior executives in certain circumstances. These policies are recommended in most EU jurisdictions, including the UK, and are mandated by legislation in the USA and the Netherlands. The Australian Federal Government has proposed to amend the Corporations Act 2001 in order to provide for an executive remuneration clawback. Notably, the South African regulatory framework in relation to the director and executive remuneration does not provide for remuneration clawbacks. However, South Africa's remuneration practice as is the case with Australia - follows the UK and US practice with its strong emphasis on the payment of bonuses and the use of share-based

"Regulating Banking Bonuses in the European Union: A Case Study in Unintended Consequences" 2013 19(4) European Financial Management 631 631; Thomas and Hill Research Handbook on Executive Pay (2012) 220-223.

2 As discussed below, remuneration clawbacks are recommended in most EU jurisdictions and are mandated by legislation in the US and the Netherlands. The other various regulatory mechanisms include strengthening the remuneration committees' independence, mandatory disclosure of remuneration packages and their links to performance as well as giving shareholders a vote on remuneration policies and packages. See generally Hill "Regulating Executive Remuneration: International Developments in the Post-scandal Era" 20063 European Company Law 64; Hill and Yablon "Corporate Governance and Executive Remuneration: Rediscovering Managerial Positional Conflict" 200225 University of New South Wales LJ 294 301-306; Luiz "Executive Remuneration and Shareholder Voting" 2013 25 SA Merc LJ 267269.

3 See Shields, O'Donnel and O'Brien “The Bucks Stop Here: Private Sector Executive Remuneration in Australia" A Report prepared for the Labour Council of New South Wales 2003 http://www.researchgate.net/publication/242042789 (accessed 2016-10-03) 13; Sykes "Overcoming Poor Value Executive Remuneration: Resolving the Manifest Conflicts of Interest" 2002 10(4) Corporate Governance: An International Review 256 258; Bruce, Buck and Main "Top Executive Remuneration: A View from Europe" 2005427 Journal of Management Studies 1493 1495; Fried and Shilon "Excess-Pay Clawbacks" 2011 36(4) The Journal of Corporation Law 721 725; Murphy 2013 19(4) European Financial Management 633; Hannes "Compensating for Executive Compensation: The Case for Gatekeeper Incentive Pay" 2010 98(2) California LR 385 386; Massie, Collier and Crotty Executive Salaries in South Africa: Who should have a Say on Pay? (2014) 35.

Cullen Executive Compensation in Imperfect Financial Markets (2014) 21.

Fried and Shilon 2011 36(4) The Journal of Corporation Law 725.

Cullen Executive Compensation in Imperfect Financial Markets 29-36; Hannes 2010 98(2) California LR 387-388; Fried and Shilon 2011 36(4) The Journal of Corporation Law 727728. 
incentives. $^{7}$ Furthermore, in South Africa, where the issues relating to director and executive remuneration ${ }^{8}$ have not yet been resolved, ${ }^{9}$ very little attention has been paid to the issue of incorporating remuneration clawbacks in the current regulatory framework. ${ }^{10}$

The purpose of this article is to explore clawbacks as a means of addressing problematic executive remuneration. This is done by an examination of the approaches adopted by the USA, Australia and certain European Union (EU) member states, and by highlighting the lessons that South Africa may draw from the experiences in these jurisdictions. The article will first consider the intentions and assumptions of remuneration reform, which have introduced clawbacks in these foreign jurisdictions. It will then move on to provide an overview of the US, Australian and EU clawback reforms, identifying and analysing the potential benefits and shortcomings of the regulatory reforms in each jurisdiction. Finally, the article offers recommendations on how remuneration clawbacks could be effectively incorporated into the South African regulatory framework.

\section{2}

\section{POLICY ISSUES}

One of the underlying policy justifications for remuneration clawbacks is that they can contribute to transparency and efficiency in the market through discouraging excessive risk-taking and short-termism. ${ }^{11}$ Inappropriate focus on the short-term objectives such as excessive risk-taking in pursuit of shortterm targets and incentives may potentially be detrimental to the long-term interests of the company and its stakeholders. ${ }^{12}$ Clawbacks are therefore designed to deter executives from pursuing inappropriate strategies that

Massie et al Executive Salaries in South Africa: Who should have a Say on Pay? 35.

Including disclosure of such remuneration.

For a discussion of the vexed question of the remuneration of company directors and executives in South Africa, see generally Madlela and Lehloenya "The Regulation of Executive Remuneration in South Africa" 2016 37(1) Obiter 1; Massie et al Executive Salaries in South Africa: Who should have a Say on Pay?; Luiz 201325 SA Merc LJ 267; Scholtz and Smit "Executive Remuneration and Company Performance for South African Companies Listed on the Alternative Exchange (AltX)" 201216 Southern African Business Review 21; Cassim, Cassim, Cassim, Jooste, Shev and Yeats Contemporary Company Law (2012) 455-456; Collier, Idensohn and Adkins "Income Inequality and Executive Remuneration: Assessing the Role of Law and Policy in the Pursuit of Equality" 2010 34(2) South African Journal of Labour Relations 84; Luiz "An Appropriate Regime for the Remuneration of Executives" 200639 Comparative and International Law Journal of Southern Africa 57; Mongalo "Shareholder Activism in the United Kingdom Highlights the Failure of Remuneration Committees: Lessons for South Africa" 2003120 SALJ 756.

10 Although Lehloenya and the author touched on the issue of remuneration clawbacks in South Africa towards the end of their article on the regulation of executive remuneration in South Africa in general, our discussion of the issue was rather superficial and lacked indepth explanation, elaboration, analysis and evaluation of the intentions and effects of introducing clawbacks as well as on how the practical challenges in the implementation of clawbacks could be addressed, especially via legislative provisions. See Madlela and Lehloenya 2016 37(1) Obiter 15-18.

11 Cullen Executive Compensation in Imperfect Financial Markets 185; Thomas and Hill Research Handbook on Executive Pay 231-232.

12 See eg, Senate Report No. 111-176 "The Restoring American Financial Stability Act of 2010" $2010 \quad 39-40$ https://www.gpo.gov/fdsys/pkg/CRPT-111srpt176/pdf/CRPT111srpt176.pdf (accessed 2016-10-03). 
would enable them to benefit from short-term increases in the company's value, but which could potentially undermine the sustainability of the company in the long-term. In this way, clawbacks help focus the attention of directors and executives on managing the companies in the long-term interests of the shareholders. They serve, consequently, as a risk management tool.

Clawbacks may also contribute to transparency and efficiency in the market by discouraging the manipulation of data by executives in order to increase their bonuses. ${ }^{13}$ There are a number of examples of executives who have overstated their companies' financial results by large amounts in order to boost their bonuses and gains from the sale of their shares. ${ }^{14}$ Clawbacks may therefore, serve as a preventative measure to discourage greedy executives from deliberately inflating and manipulating earnings and other performance criteria for self-serving ends. ${ }^{15}$

Clawbacks are designed to allow companies to recover overpaid remuneration that has been erroneously paid to the executives. ${ }^{16}$ As such, clawbacks play an important role in preventing the unfair diversion of funds from the company and its stakeholders to overpaid remuneration. ${ }^{17}$ Overpaid remuneration may further impose substantial costs on companies and other stakeholders. ${ }^{18}$ Overpaid remuneration is also undeserved and, as such, undermines pay-performance sensitivity. The orthodox purpose of performance-based remuneration is to motivate executives to work hard and to create long-term value for the company and its stakeholders. Allowing executives to retain unearned remuneration in the form of overpaid incentives defeats this primary purpose of incentive-based remuneration. Therefore, clawbacks can play a role in aligning executive incentives with actual performance and long-term sustainability of the company. ${ }^{19}$

Arguments advanced against remuneration clawbacks include that they may have the undesirable effect of reducing the use of incentive pay particularly where such policies are mandated by legislation. ${ }^{20}$ It has been

13 Cullen Executive Compensation in Imperfect Financial Markets 185.

14 Markham "Regulating Excessive Executive Compensation - Why bother?" 2007 2(2) Journal of Business and Technology 277 296-298; Fried and Shilon 2011 36(4) The Journal of Corporation Law 727-728.

15 Markham 2007 2(2) Journal of Business and Technology 296-298; Fried and Shilon 2011 36(4) The Journal of Corporation Law 727-728. See also Denis, Hanouna and Sarin "Is There a Dark Side to Incentive Compensation?" 200612 Journal of Corporate Finance 467 $467-486$, for a discussion on how share options may incentivise the executives to engage in fraudulent activities.

16 Cullen Executive Compensation in Imperfect Financial Markets 185.

17 See Senate Report Senate Report No. 111-176 https://www.gpo.gov/fdsys/pkg/CRPT111srpt176/pdf/CRPT-111srpt176.pdf 136.

18 Fried and Shilon 2011 36(4) The Journal of Corporation Law 725-729.

19 Fried and Shilon 2011 36(4) The Journal of Corporation Law 735.

20 See Romano and Bhagat 2009 26(2) Yale Journal on Regulation 366; Bainbridge "DoddFrank: Quack Federal Corporate Governance Round II" 201195 Minnesota LR 1779 1807; Australian Institute of Company Directors Submission by the Australian Institute of Company Directors to Federal Treasury in relation to the Discussion Paper "The Clawback of Executive Remuneration where Financial Statements are Materially Misstated" 2011 http://www.companydirectors.com.au/ /media/C9BCA81BC4914B6584B5B6D22B11E90A. ashx (accessed 2016-10-03) 9; Cohen, Dey and Lys "The Sarbanes Oxley Act of 2002: Implications for Compensation Structure and Risk-taking Incentives of CEOs" 2004 
asserted that increased risk of liability may discourage entrepreneurship and may lead to increased risk-aversion in the executives. ${ }^{21}$ This, it has been argued, may be costly to companies and shareholders as it reduces incentives to create value. ${ }^{22}$ It has also been contended that clawbacks may make it difficult for companies to attract, retain and properly incentivise skilled directors and executives. ${ }^{23}$

It is, however, submitted that there are cogent policy considerations in favour of remuneration clawbacks as discussed above. Robust clawback policies would arguably enhance the company's value in the long-term through encouraging sound risk management, accountability and responsible management of companies, as well as the prevention of the diversion of corporate funds. In my view, it would serve the interests of South Africa if carefully considered clawback policies were to be incorporated into the country's regulatory framework. This would be in line with section 7 of the Companies Act of 2008 that lists encouraging transparency and high standards of corporate governance together with encouraging efficient and responsible management of companies as some of the aims of this Act. ${ }^{24}$

\section{CLAWBACKS IN THE USA}

In the USA, the clawback of performance-based incentives is provided for in three federal statutes: the Sarbanes Oxley Act of $2002 ;^{25}$ the Emergency Economic Stabilization Act of $2008 ;{ }^{26}$ and the Dodd-Frank Wall Street Reform and Consumer Protection Act of $2010 .^{27}$ These statutes were enacted amidst widespread concerns about problematic remuneration arrangements and perverse incentives in the USA. This part will examine the relevant provisions of these statutes.

\section{The Sox}

The US regulatory authorities responded to the accounting scandals, frauds and corporate governance failures in large companies such as Enron,

http://leeds-faculty.colorado.edu/bhagat/SOX-CEO-Compensation-Investment.pdf (accessed 2016-10-04) 3-4.

21 Romano and Bhagat 2009 26(2) Yale Journal on Regulation 366; Bainbridge 201195 Minnesota LR 1807; Australian Institute of Company Directors http://www.company directors.com.au/ /media/C9BCA81BC4914B6584B5B6D22B11E90A.ashx 9; and Cohen, Dey and Lys http://leeds-faculty.colorado.edu/bhagat/SOX-CEO-CompensationInvestment.pdf 3-4.

22 Romano and Bhagat 2009 26(2) Yale Journal on Regulation 366; Bainbridge 201195 Minnesota LR 1807; Australian Institute of Company Directors http://www.companydirec tors.com.au/ /media/C9BCA81BC4914B6584B5B6D22B11E90A.ashx 9; and Cohen, Dey and Lys http://leeds-faculty.colorado.edu/bhagat/SOX-CEO-Compensation-Investment.pdf (accessed 2016-10-04) 3-4.

23 Australian Institute of Company Directors http://www.companydirectors.com.au/ /media/C9 BCA81BC4914B6584B5B6D22B11E90A.ashx 9.

24 See s 7(b)(iii) and (j) of the Companies Act 71 of 2008.

25 Hereinafter "SOX".

26 Hereinafter "EESA".

27 Hereinafter "Dodd-Frank". 
WorldCom and Global Crossing by passing the SOX. ${ }^{28}$ The clawback provisions in SOX are found in section 304. In terms of section 304(a), if a company is required to prepare an accounting restatement due to its material non-compliance, as a result of misconduct with any financial reporting requirement under the securities laws, the chief executive officer (CEO) and chief financial officer (CFO) of the company must reimburse the company for: (1) any bonus or other incentive-based or equity-based compensation received by that person from the company during the twelvemonth period following the first public issuance or filing with the Securities and Exchange Commission (SEC) - whichever occurs first - of the financial document giving rise to the required restatement, and (2) any profits realised from the sale of securities of the company during that 12-month period. Section 304(b) affords the SEC the discretion to exempt any person from the application of subsection (a), as it deems necessary and appropriate.

Notably, the liability of the CEO and CFO is up to the full amount of the bonus or other incentives and profits realised from stock sales during the specified period. When compared with the equivalent provision in DoddFrank - which provides for the recovery of incentive-based compensation in excess of what would have been awarded had the financial statement been correct $^{29}$ - section 304(a) of SOX has potentially very harsh and punitive consequences. ${ }^{30}$ In addition to facilitating ex post facto recovery by the company of erroneously paid incentives, the provision was clearly designed to be an effective deterrence to corporate misconduct, which could result in financial restatements. ${ }^{3}$

However, the efficacy of the clawback provisions in SOX in fostering good remuneration practices is not without concerns. For example, it was contended in the USA that companies adapted to section 304 of SOX by increasing the portion of the executives' remuneration which was not subject to a potential clawback - for example, fixed-salary - while decreasing performance-based incentives which were subject to a potential clawback in order to minimise the high risk involved. ${ }^{32}$ This had the unintended effect of undermining pay for performance and its attendant benefits. ${ }^{33}$

Section 304 of SOX is also widely criticised on the ground that the circumstances in which this provision may be invoked are severely limited. The obligation of the CEO and CFO to reimburse the company is triggered by accounting restatements only in cases where there has been sufficiently serious misconduct by the company. ${ }^{34}$ Therefore, in order to rely on section

28 The SOX contained far-reaching provisions aimed at strengthening corporate governance and accurate financial reporting in public companies.

29 See s 954 of Dodd-Frank, as discussed below.

30 Fried and Shilon 2011 36(4) The Journal of Corporation Law 730.

31 Ibid.

32 Cohen, Dey and Lys http://leeds-faculty.colorado.edu/bhagat/SOX-CEO-CompensationInvestment.pdf 22.

33 Ibid. See also Romano and Bhagat 2009 26(2) Yale Journal on Regulation 366; Bainbridge 201195 Minnesota LR 1807.

34 See SEC v Jenkins, 718 F. Supp. 2d 1070, 1074-77 (D Ariz. 2010). The court further stated that before reimbursement can be required, the company's misconduct must also be sufficiently serious to result in material non-compliance with a financial reporting 
304, the SEC must prove a sufficiently serious misconduct. This could lead to unnecessary and expensive litigation. ${ }^{35}$ It has also been pointed out that overpaid incentives do not always occur as a result of misconduct by the company. ${ }^{36}$ Furthermore, ooverpaid incentives - even if they are not the result of misconduct - can still impose substantial costs on companies and other stakeholders. ${ }^{37}$ It is also worth noting that financial misstatements, whether as a result of misconduct or unintentional error, may be sufficiently extensive to influence the decision making of investors and other stakeholders. ${ }^{38}$ It has, accordingly, been observed that in practice section 304 of SOX has not been effective in addressing the problem of overpaid incentives based on the requirement of an act of misconduct. ${ }^{39}$

Furthermore, the range of individuals from whom performance-based incentives may be recouped under section 304 is very restricted as the liability to reimburse the company applies only to the CEO and CFO. Limiting the application of a clawback to these two executives excludes other officers who also occupy influential roles in the management of the company and in the preparation of financial statements. It is also not clear from the wording of section 304 whether the clawback would apply to former executives as well.

The other weakness of section 304 is that it can only be invoked by the SEC. ${ }^{40}$ Neither the company nor the shareholders have the loci standi to sue the CEO and CFO for recovery of the overstated incentives under section 304. This is problematic. It has been observed that clawback litigation may be protracted and very costly to the SEC. ${ }^{41}$ This may deter the SEC from actively pursuing clawbacks under SOX provisions. ${ }^{42}$

\section{The EESA}

The clawback provisions of the EESA apply only to financial institutions receiving financial assistance under the Treasury Department's Troubled Asset Relief Programme (TARP), which are yet to repay the Treasury Department. $^{43}$ In 2009, Congress amended the EESA to introduce restrictions on the salaries and bonuses of the executives of these

requirement under the securities laws, and must require the issuer to file an accounting restatement.

35 Fried and Shilon 2011 36(4) The Journal of Corporation Law 731.

36 Fried and Shilon 2011 36(4) The Journal of Corporation Law 726.

37 Fried and Shilon 2011 36(4) The Journal of Corporation Law 731.

38 Australian Government "The Clawback of Executive Remuneration where Financial Statements are Materially Misstated" (Discussion Paper) 2010 http://archive.treasury.gov. au/documents/1926/PDF/101220\%20Clawback\%20of\%20executive\%20remuneration\%20\%20Final\%20-\%20Approved.pdf (accessed 2016-10-03) 3.

39 The SEC has only been able to pursue the clawback against executives criminally convicted of fraud. See Markham 2007 2(2) Journal of Business and Technology 299; Fried and Shilon 2011 36(4) The Journal of Corporation Law 730-731.

$40 \quad$ Neer v Pelino 389 F. Supp. 2d 468, 657 (E.D Pa. 2005).

41 Fried and Shilon 2011 36(4) The Journal of Corporation Law 731.

42 lbid.

43 See s $11(\mathrm{~b})$ and (c) of EESA. 
institutions. ${ }^{44}$ This followed outrage about the "Wall Street bonus culture" which was widely believed to have contributed to the excessive risk-taking that fuelled the global financial crisis and the massive bonuses paid by troubled financial institutions to their executives after receiving government funding under the TARP. ${ }^{45}$ Section $111(\mathrm{~b})(3)(\mathrm{B})$ of the EESA ${ }^{46}$ empowers the Secretary to require that the financial institution receiving assistance under the TARP meet appropriate standards for executive compensation and corporate governance. The standards required under this subsection include a provision for the recovery by the financial institution of any bonus or incentive compensation paid to a senior executive officer based on statements of earnings, gains, or other criteria that are later proven to have been materially inaccurate.

There are notable differences between the clawback provisions of SOX and EESA. The clawback under the EESA is triggered by statements of earnings, gains, or other criteria that are later proven materially inaccurate whereas SOX clawback is triggered by an accounting restatement due to the company's non-compliance, as a result of misconduct, with any financial reporting requirement under the securities laws. A financial restatement under securities laws is not a requirement under EESA. Secondly, misconduct on the part of the company is not required to trigger the recovery or clawback under the EESA. Whereas the SOX clawback may be invoked only against the CEO and CFO of the company, the EESA clawback may be invoked against a senior executive officer. ${ }^{4}$

The EESA does not provide for a time period during which the recovery will operate whereas only incentive compensation received within the twelvemonth period following the first public issuance or filing of the misleading financial statement may be recouped under SOX. Furthermore, the EESA clawback may be invoked by the company. This is an improvement when compared to the SOX clawback provision that may only be invoked by the SEC.

The similarity with SOX is that the recovery or clawback under the EESA is of any bonus or incentive compensation paid. A "senior executive officer" may thus be held liable up to the full amount of the bonus or incentive compensation.

\section{Dodd-Frank}

Public concerns over the Wall Street bonus culture and the role that excessive executive incentives were believed to have played in contributing to the financial crisis resulted in the adoption of Dodd-Frank in July 2010.

44 These restrictions were introduced by the American Recovery and Reinvestment Act (hereinafter "ARRA") of 2009.

45 See Romano and Bhagat 2009 26(2) Yale Journal on Regulation 360.

46 Inserted by s 7001 of ARRA.

47 The term "senior executive officer" for the purposes of this provision is defined to mean an individual who is one of the top 5 highly paid executives of a public company, whose compensation is required to be disclosed pursuant to the Securities Exchange Act of 1934, and any regulations issued thereunder, and non-public company counterparts. 
Section 954 of Dodd-Frank amended the Securities Exchange Act of $1934^{48}$ by inserting a new section $10 \mathrm{D}$ that provides for the recovery of erroneously awarded compensation. ${ }^{49}$ Section $10 \mathrm{D}$ requires the SEC to direct, by rule, the national securities exchanges and national securities associations to prohibit the listing of any security of a company that does not comply with the requirement of disclosure, inter alia, of its policy on the recovery of erroneously awarded compensation. In terms of section $10 \mathrm{D}(\mathrm{b})(2)$ the policy on the recovery of erroneously awarded compensation must provide as follows:

"[T]hat, in the event that the issuer is required to prepare an accounting restatement due to the material non-compliance of the issuer with any financial reporting requirement under the securities laws, the issuer will recover from any current or former executive officer of the issuer who received incentive-based compensation (including stock options awarded as compensation) during the 3-year period preceding the date on which the issuer is required to prepare an accounting restatement, based on the erroneous data, in excess of what would have been paid to the executive officer under the accounting restatement." (author's own emphasis).

In contrast to SOX, section 10D of the SEC Act has broadened and refined the circumstances in which clawback of excess performance-based compensation will apply. Section 10D applies to any current and former executive officer of the company and not only to the current CEO and CFO. However, the provision has not defined "executive officer" in relation to the clawback.

It is also worth noting that section $10 \mathrm{D}$ does not require misconduct to trigger the clawback. The clawback applies to excess incentive-based compensation awarded during the three-year period preceding the date of the accounting restatement. The company is required to recover the overpaid incentives. The amount that must be clawed back is the incentivebased compensation in excess of what would have been paid to the executive officer absent the material non-compliance with the financial reporting requirements. ${ }^{50}$

Moreover, the clawback in section 10D applies to all listed companies. Further, a clawback policy under this section must require the company to recover excess or overpaid incentive-based compensation. The statute does not give the company the discretion not to effect the clawback. It has been asserted, in support of this approach, that giving the company the discretion to consider whether or not to effect the clawback could undermine the desirable deterrent effects associated with requiring recovery of overpaid incentive-based compensation. ${ }^{5}$

The overall effect of section $10 \mathrm{D}$ is that the disclosure and policy requirement should apply in a very broad manner to all listed companies. It

48 Hereinafter "the SEC Act".

49 See s 954 of the Dodd-Frank Wall Street Reform and Consumer Protection Act of 2010.

50 According to the Senate Report the intention of the clawback under S 10D is to enable companies to recover the "money that the executive would not have received if the accounting was done properly and was not entitled to." See Senate Report https://www. gpo.gov/fdsys/pkg/CRPT-111srpt176/pdf/CRPT-111srpt176.pdf 135

51 Fried and Shilon 2011 36(4) The Journal of Corporation Law 739. 
has, however, been asserted that although section 10D of the SEC Act is a remarkable improvement from section 304 of SOX and would likely improve remuneration arrangements in public companies, there are notable weaknesses even with its improved provisions. For instance, the clawback in section $10 \mathrm{D}$ is triggered only by financial restatements resulting from a company's material non-compliance with financial reporting requirements. This has been criticised for limiting the circumstances in which overpaid remuneration can be recovered since executives could receive excess incentive-based remuneration even if a restatement is not required. ${ }^{52}$ It has thus been suggested that companies should be allowed to recover overpaid remuneration regardless of whether or not a restatement is required. ${ }^{53}$ In addition, focusing solely on financial metrics would restrict the operation of the clawback since companies may use non-financial metrics and other circumstances to determine incentive-based remuneration. ${ }^{54}$

\section{SEC proposed rules on clawbacks}

On 1 July 2015, the SEC proposed a new Securities Exchange Act Rule $10 \mathrm{D}-1^{55}$ to implement the clawback provisions of section 10D of the SEC Act, discussed above, directing US securities exchanges and associations to establish listing standards that would require all listed companies to adopt policies requiring executive officers to pay back erroneously awarded incentive-based compensation. ${ }^{56}$ Under Rule $10 \mathrm{D}-1$ a company would be subject to delisting if it does not adopt a clawback policy as required, or if it does not disclose the policy or comply with the policy's recovery provisions.

\section{Companies subject to proposed Rule 10D-1}

Rule 10-D applies generally to all listed companies, including emerging growth companies, smaller reporting companies, foreign private companies and controlled companies. In the opinion of the SEC, the policy reasons for clawing back overpaid incentive-based compensation, discussed above, apply to all listed companies regardless of type or size. ${ }^{57}$ This approach may possibly be criticised on the premise that the category of companies or issuers to which the clawback applies is too wide. It has, for example, been argued that private companies should be exempted from Rule 10-D as, unlike in large public companies, significant conflicts of interests and agency problems between shareholders and directors do not arise in the context of

\footnotetext{
Fried and Shilon 2011 36(4) The Journal of Corporation Law 748-749.

Ibid.

Ibid.

Hereinafter "Rule 10D-1".

56 See SEC Release "Listing Standards for Recovery of Erroneously Awarded Compensation (Proposed Rule) 17 CFR PARTS 229, 240, 249 and 274 [Release Nos. 33-9861; 3475342; IC-31702; File No. S7-12-15] RIN 3235-AK99" 2015 https://www.sec.gov/rules/ proposed/2015/33-9861.pdf (accessed 2016-10-03). See also Federal Register / Vol. 80, No. 134 / Tuesday, July 14, 2015 / Proposed Rules (July 2015) https://www.gpo.gov/fdsys/ pkg/FR-2015-07-14/pdf/2015-16613.pdf (accessed 2016-10-04).

57 SEC Release https://www.sec.gov/rules/proposed/2015/33-9861.pdf 12.
} 
private companies. ${ }^{58}$ While this argument may be to an extent sound, sight should not be lost of the fact that there exist private companies in the modern day corporate world that are significantly large and that have a clear separation of ownership and management.

Having considered the relative burden of compliance on all listed companies, the SEC concluded that even relatively small companies, their shareholders and the market would benefit from the clawback requirement. ${ }^{59}$ Notably, the SEC has proposed to exempt certain categories of companies from the application of the clawback. For example, registered investment management companies that have not awarded incentive-based compensation to any of their executive officers would be excluded from the application of Rule 10-D. It has also been proposed that UITs ${ }^{60}$ would also be exempted from the rule. These exemptions make sense, as incentivebased remuneration does not apply to these categories of companies.

\section{The trigger of the clawback}

The clawback in section 10D of the SEC Act is triggered when the company is required to prepare an accounting restatement due to material noncompliance with any financial reporting requirement under the securities laws. Accordingly, Rule 10D-1 proposes that the clawback will be triggered in the event that the company is required to prepare an accounting restatement due to a material error that affects a financial reporting measure based on which executive officers received incentive-based compensation. ${ }^{61}$ What constitutes "material" error will depend on the facts and circumstances of each case. ${ }^{62}$

No misconduct or wrongdoing on the part of the company or executive officer is required to trigger the clawback under the proposed Rule 10D-1. The role of the executive in preparing the financial statement is also immaterial in determining whether the clawback applies. It is submitted that the absence of the requirement for misconduct or wrongdoing on the part of the company or individual concerned makes sense since, as discussed above; overpaid remuneration may occur regardless of whether there was misconduct or wrongdoing. ${ }^{63}$ It, therefore, follows that the clawback in section 10D of the SEC Act and Rule 10D-1 is regarded as an equitable remedy against unjust enrichment, which needs not be triggered by misconduct.

58 See eg, Fried "Comments on Proposed Rule: Listing Standards for Recovery of Erroneously Awarded Compensation [Release Nos. 33-9861, 34-75342, IC-31702; File No. S7-12-15] (2016)" (2016) available at https://www.sec.gov/comments/s7-12-15/s71215-68.pdf (accessed 2016-10-04) 38-39.

59 SEC Release https://www.sec.gov/rules/proposed/2015/33-9861.pdf 12.

60 le, pooled investment entities without a board of directors, corporate officers, or an investment adviser to render investment advice.

61 In terms of Rule 10D-1(c)(1) an accounting restatement refers to a required revision of previously issued financial statements to reflect the correction of one or more errors that are material to those financial statements.

62 SEC Release https://www.sec.gov/rules/proposed/2015/33-9861.pdf 25.

63 See par 31 above. 


\section{The category of individuals to whom Rule 10D-1 would apply}

The clawback in section 10D of the SEC Act applies to any current or former "executive officer" of the company. According to Rule 10D-1 "executive officer" would include the company's president, principal financial officer, principal accounting officer, any vice president in charge of a principal business unit, division or function, any other officer who performs a policymaking function, or any other person who performs similar policy-making functions for the company. ${ }^{64}$ Executive officers of the company's holding company or subsidiaries would be deemed to be "executive officers" of the company if they perform a policy-making function for the company. ${ }^{65}$ This would include officers with a significant role in financial reporting.

It has been contended that Rule $10 \mathrm{D}-1$ is undesirable as a deterrence to financial misreporting in so far as it applies to a too wide category of individuals, particularly in large listed companies, including the less influential individuals when it comes to financial reporting. ${ }^{66}$ This, it has been argued, may lead to an unnecessary compliance burden. ${ }^{67}$ It is, however, submitted that in addition to serving as deterrence to financial misreporting, Rule 10D-1 should be viewed as a remedy against the unjust enrichment of company executives that may also be costly to the company. Viewed in that light, there is nothing wrong with extending the application of the clawback to executive officers of the company. The challenges surrounding the practicality of extending the clawback to "less senior" executive officers, in my view, may be remedied by giving the board of directors a degree of discretion whether to seek recovery of erroneously awarded incentives. Such directorial discretion should, however, be subject to necessary safeguards such as appropriate disclosure requirements and the requirement that the board must genuinely believe that seeking recovery would not be in the best interests of the company. This will help prevent abuse.

\section{Types of incentive-based compensation that is subject to Rule 10D-1}

The incentive-based compensation that would be subject to the clawback provisions of Rule 10D-1 is defined widely to mean any compensation that is granted, earned or vested based wholly or in part upon the attainment of any financial reporting measure. ${ }^{68}$ Accordingly, incentives based on nonfinancial metrics like operational, event-based, or strategic goals would not

\footnotetext{
Rule 10D-1(c)(3).

Rule 10D-1(c)(3).

66 See eg, Fried https://www.sec.gov/comments/s7-12-15/s71215-68.pdf 48-50.

67 Ibid.

68 Rule 10D-1(c)(4). Financial reporting measures would include accounting-based measures such as revenues, net income, operating income, financial ratios, net assets or net asset value per share, EBITDA, funds from operations, liquidity measures, return measures and earnings measures. See SEC Release https://www.sec.gov/rules/proposed/2015/33 9861.pdf 42-43.
} 
be subject to the clawback policy under Rule 10D-1. ${ }^{69}$ Furthermore, compensation that is not based on satisfying a financial reporting measure, such as base salaries or incentives awarded upon completion of a specified employment period and discretionary bonuses, would not be subject to the clawback. $^{70}$

\section{Determination of the recoverable amount}

The clawback would apply to any incentive-based compensation paid to the executive officers in excess of what otherwise would have been received had it been determined based on the accounting restatement. ${ }^{71}$ Under Rule 10D-1 the recoverable amount is to be determined by the company by way of mathematical recalculation based on the information in an accounting restatement. It would, therefore, be relatively easy to determine overpaid incentives based on an accounting restatement. However, the determination of incentive-based compensation based on share price or total shareholder return would be quite problematic. Rule 10D-1(b)(1)(iii)(A) suggests that in such a case the recoverable amount may be determined based on a reasonable estimate of the impact of the accounting restatement on the performance measure. ${ }^{72}$ Although this approach is intended to mitigate the potential complexities and costs which may be involved in establishing the relationship between an accounting error and the share price, ${ }^{73}$ it would unlikely lead to an accurate determination of overpaid incentives received as a result of the financial misreporting.

Notably, the recoverable amount would be determined without regard to any taxes paid by the executive officer, as the SEC believes that such recovery on a pre-tax basis would be in line with the policy underpinning the Dodd-Frank clawback - it would ensure that the company recovers the full amount of the erroneously awarded incentive-based compensation. It would also relieve the company of the administrative complexities associated with calculating the recoverable amount based on the specific tax circumstances of each executive officer. It is submitted that this aspect of Rule 10D-1 is quite problematic as it is unduly punitive on the executive officers. The tax implications of the clawback should, therefore, be carefully considered and addressed in the Dodd-Frank clawback.

\section{The time period over which the clawback should be applied}

The proposed Rule 10D-1 provides that the clawback would apply to any incentive-based compensation received within the three fiscal years preceding the date on which a company is required to prepare an accounting

9 SEC Release https://www.sec.gov/rules/proposed/2015/33-9861.pdf 45.

70 SEC Release https://www.sec.gov/rules/proposed/2015/33-9861.pdf 46-47.

71 Rule 10D-1(b)(1)(iii).

72 In such a case, the company is required to keep documentation on how the reasonable estimate was determined and furnish the securities exchange with such documentation.

73 SEC Release https://www.sec.gov/rules/proposed/2015/33-9861.pdf 44. 
restatement. ${ }^{74}$ The clawback would apply to excess incentive-based compensation received by a person who was an executive officer of the company at any time during the performance period for that incentive-based compensation. ${ }^{75}$

\section{Board discretion regarding the application of the clawback}

Under Rule 10D-1 the company is obliged to clawback erroneously awarded incentive-based compensation from its executive officers in compliance with its clawback policy except where it would be impracticable to do so because the costs of pursuing the clawback would exceed the recoverable amount or where the recovery would violate the company's home country law. However, in both instances, the company would be required to first make a reasonable attempt to clawback the incentive-based compensation. ${ }^{76}$ It must document its attempts to clawback the compensation and provide the documentation to the relevant exchange. The company would also be required to provide an explanation as to why it decided not to pursue the clawback. The decision not to pursue the clawback must be made by an independent remuneration committee of the company and such decision may be reviewed by the relevant exchange. ${ }^{77}$

These rules are clearly designed to prevent the circumvention of the Dodd-Frank clawback provisions in instances where company boards are afforded a wide discretion whether to recoup overpaid incentives. At the same time, they signify the SEC's appreciation of the fact that seeking clawback in situations where the costs of recovery exceed the amount of erroneously awarded incentive-based compensation would generally not be in the interests of the company and its stakeholders.

\section{Indemnity and directors' insurance}

The proposed Rule 10D-1 would prohibit companies from indemnifying executive officers against the loss of erroneously awarded incentive-based compensation. Having considered that the clawback under section 10D of the SEC Act applies on a no-fault basis, the SEC came to the conclusion that indemnification arrangements would be undesirable as they would nullify the purpose of section 10D.

\footnotetext{
Rule 10D-1(b)(ii)

Rule 10D-1(b)(1)(i)(B)

Rule 10D-1(b)(1)(iv)

Rule 10D-1(b)(1)(iv). In cases where the company decides that recovery would be impracticable because seeking recovery would violate the home country law, the company would be required to first obtain an opinion of home country counsel, acceptable to the relevant exchange, that recovery would violate the home country law.

78 SEC Release https://www.sec.gov/rules/proposed/2015/33-9861.pdf 70.
} 


\section{Disclosure}

In line with section 10D of the SEC Act, the proposed Rule 10D-1 would require a listed company to disclose its clawback policy as an exhibit to its annual report. If during the company's preceding fiscal year, there was a restatement that triggered the clawback or there was an outstanding balance of excess incentive-based compensation from a prior restatement, then the company would need to disclose the following information: ${ }^{79}$

- the date on which the restatement was required;

- the total amount of excess incentive-based compensation attributable to the restatement;

- the total amount of excess incentive-based compensation that is outstanding at the end of the company's last completed fiscal year; and

- the estimates used to determine the excess compensation in the case of compensation based on share price or total shareholder return;

Furthermore, if the issuer decided not to pursue recovery, then the name of each executive officer subject to recovery, the amount forgone and the reason for not to pursuing recovery must be provided. If the excess compensation has been outstanding for 180 days or longer, the name of the officer and the outstanding amount must be disclosed. These disclosure requirements are aimed at increasing transparency, thereby informing shareholders' voting and investment decisions. ${ }^{80}$ It is also hoped that the disclosure would ensure compliance with the listing standards of the various stock exchanges. ${ }^{81}$

\section{CLAWBACK REFORMS IN AUSTRALIA}

\section{The discussion paper on clawbacks}

As is the case in the USA and UK, excessive and inappropriate remuneration practices have continued to raise considerable controversy in Australia. One of the responses of the Australian government to the community concerns against questionable executive bonuses and incentives was the introduction of the clawback proposal that was subsequently followed by the release of a clawback discussion paper in December 2010. ${ }^{82}$ The essence of the proposed clawback proposal was that the directors and executives should be obliged to repay the company any remuneration paid to them based on the company's financial statements that turn out to be materially misstated. ${ }^{83}$ This, according to the discussion paper, could be a

79 The information is to be provided in the listed company's next proxy statement or, if the company does not file a proxy statement, in its next annual report. See Item $402(w)$ of Regulation S-K.

80 SEC Release https://www.sec.gov/rules/proposed/2015/33-9861.pdf 84.

81 Ibid.

82 Australian Government http://archive.treasury.gov.au/documents/1926/PDF/101220\%20 Clawback\%20of\%20executive\%20remuneration\%20-\%20Final\%20-\%20Approved.pdf.

83 Australian Government http://archive.treasury.gov.au/documents/1926/PDF/101220\%20 Clawback\%20of\%20 executive\%20remuneration\%20-\%20Final\%20-\%20Approved.pdf 3. 
recoupment of remuneration already paid to the executive, or a cancellation of an outstanding but unvested and unpaid future award. ${ }^{84}$ The discussion paper posed, inter alia, the following key considerations in relation to the formulation of rules regarding the implementation of the clawback:

- whether the clawback should be implemented through legislation, best practice principles, or a mixture of the two;

- which companies should the clawback apply to;

- which members of the executive board should it apply to;

- what kind of event would trigger a clawback;

- the determination of an appropriate amount of the clawback;

- when the clawback amount would need to be repaid;

- whether intention or misconduct should be considered in the clawback provision;

- how far back should the clawback apply; and

- who should bear the responsibility for applying the clawback?

There has been considerable debate concerning the desirability of legislating clawbacks in Australia. One of the major stakeholders who supported the clawback mechanism, the Australian Council of Super Investors (ACSI), argued that the clawback should be facilitated through appropriate changes to the Corporations Act of $2001 .{ }^{85}$

On the other hand, stakeholders such as the Australian Institute of Company Directors (AICD) strongly opposed the clawback reforms on the basis that they were totally unwarranted, would add red tape for little or no benefit and were likely to have unintended consequences on the structuring of remuneration. ${ }^{86}$ The AICD further argued that some companies already had included clawback provisions as part of their remuneration arrangements and that the appropriateness of particular forms of clawbacks would vary from company to company.

84 Ibid.

85 ACSI further suggested that directors should be accorded with a clear responsibility to declare that payments to KMP's have been validly made; that directors be sufficiently empowered to seek reimbursement of payments where they are based on a financial misstatement; and that the ASIC be accorded with the authority to instigate an action to pursue a clawback of remuneration in the event of company directors being unable to seek repayment of remuneration from KPIs within a certain time. See Australian Council of Super Investors "Submission on the Clawback of Executive Remuneration where Financial Statements are Materially Misstated" 2011 http://archive.treasury.gov.au/documents/2050/ PDF/2_Australian_Council_of_Super_Investors.pdf (accessed 2016-10-04).

86 Australian Institute of Company Directors "Pay Legislation is more unnecessary Regulation, say Directors" 2010 http://www.companydirectors.com.au/general/header/media/media-re leases/2010/pay-legislation-is-more-unnecessary-regulation-say-directors (accessed 201610-01).

87 Australian Institute of Company Directors http://www.companydirectors.com.au/general/ header/media/media-releases/2010/pay-legislation-is-more-unnecessary-regulation-saydirectors 7. The AICD further suggested that, should clawback reforms be pursued further, the clawback should be implemented via the Australian Stock Exchange Corporate Governance Council Principles; the clawback should apply to current CEO and CFO only; the responsibility for applying the clawback and the determination of the recoverable amount should be left to the company to determine; the clawback should apply to the 12 - 
Other stakeholders, although not opposed to the principle that executives should not be allowed to retain the remuneration that was determined based on misleading financial information, objected to the idea that the clawback provision should be legislated in the Corporations Act of 2001. It has been observed that most of the submissions made to the discussion paper seemed to be against the idea that the clawback should be mandated in the legislation. ${ }^{88}$ Instead, the majority of the submissions suggested that company boards or the non-binding principles of the Australian Stock Exchange (ASX) Governance Council should regulate the clawback. ${ }^{89}$ It was contended that legislation tends to be too rigid and only offers a one-sizefits-all solution that may not be suitable for all companies. ${ }^{90}$ Furthermore, according to these submissions, the rules surrounding the application of the clawback posed by the discussion paper should not be prescribed. ${ }^{91}$ It has, therefore, been suggested that companies should bear the responsibility for applying the clawback and that they should be at liberty to design their own clawback policies and to determine the recoverable amounts under those policies.

\section{Corporations Legislation Amendment Bill 2012 (Remuneration Disclosures and Other Measures)}

The Australian Federal Government released for consultation the exposure draft of the Corporations Legislation Amendment (Remuneration Disclosures and Other Measures) Bill 2012, which has not yet passed into legislation. ${ }^{92}$ The draft Bill proposes to amend the Corporations Act 2001 by adding a new requirement at the end of section $300 \mathrm{~A}(1)$. In terms of the proposed amendment, if a listed company becomes aware during the financial year of a material misstatement or omission in its financial statements for the previous 3 financial years, such company is required to report in its remuneration report for each of the key management personnel (KMP), the following information:

month period preceding the "material statement" event; and intention element should be necessary to trigger the clawback provision.

88 See Kovačević "Executive Remuneration Developments in Australia: Responses and Reactions" 2012 23(2) The Economic and Labour Relations Review 99107.

89 Ibid.

90 See eg, Chartered Secretaries Australia Submission "The Clawback of Executive Remuneration where Financial Statements are Materially Misstated" 2011 http://www.google.co.za/url?url=http://www.governanceinstitute.com.au/media/36832/Final submission clawback proposal. pdf\&rct=i\&frm $=1 \& q=\&$ es $r c=s \& s a=U \& v e d=0$ ahUKEwiXwte 6 w8fLAhXBoQ4KHRVHCjIQFggTMAA\&sig2=YeWTZIZ20bN_52NSH1vPHg\&usg=AFQjCNF VZE91EAArKPImcOLwOVvzLPXY-A (accessed 2016-10-03). Chartered Secretaries Australia (CSA) applauded publication of the discussion paper, but expressed reservations about incorporating clawbacks into legislation. In its submission, the Institute of Chartered Accountants reiterated CSA's position that should the government decide to proceed with implementing the clawback policy, it should allow companies to design appropriate policies for their remuneration frameworks.

91 See Ernst and Young Submission "The clawback of executive remuneration discussion paper: Ernst and Young submission" 2011 http://archive.treasury.gov.au/documents/2050/ PDF/11Ernst Young.pdf (accessed 2016-10-03).

92 Hereinafter "the draft Bill". 
- the details of any reduction, repayment, or other alteration of the person's remuneration made, or to be made, because of the misstatement or omission; ${ }^{93}$ or

- if a reduction, repayment or alteration of the person's remuneration has not been made, and will not be made - an explanation of why ${ }^{94}$

Notably, the clawback provisions under the draft Bill would apply to all listed companies that become aware of material misstatements or omissions in their financial statements for the previous three financial years whether or not there was any misconduct involved. The clawback would be applied by the company. The company would be entitled to reduce or seek repayment or other alteration of the erroneously awarded remuneration. The disclosures are to be made in the company's remuneration report. Thus in the event that shareholders are dissatisfied with the company's actions, they would be able to vote against the remuneration report under the "two-strikes rule" and to potentially require that all the directors resign and stand for re-election within 90 days. ${ }^{95}$

The clawback would apply to key management personnel of all listed companies. Section 9 of the Corporations Act 2001 provides that the term "key management personnel" has the same meaning as in the accounting standards. In terms of Accounting Standard AASB 124.9, "key management personnel" refers to those persons having authority and responsibility for planning, directing and controlling the activities of the entity, directly or indirectly, including any director ${ }^{96}$ of that entity. Thus, the clawback would apply to a wide category of company officers. The draft Bill is, however, silent on whether the clawback would apply to former key management personnel as well.

Although the draft Bill proposes an approach on the clawback of executive remuneration that reflects the one adopted in the USA under section 10D of the SEC Act, as inserted by Dodd-Frank, discussed above, there are significant differences between the two approaches. The draft Bill has been crafted on an "if not, why not" basis. This is not the case with section 10D. The "if not, why not" approach proposed under the draft Bill affords the company a discretion whether to pursue a reduction, repayment or alteration of the erroneously awarded remuneration. It represents a realisation that in certain situations it could not be in the interests of the company and its stakeholders to apply the clawback. The requirement to provide reasons for not seeking a reduction, repayment or alteration of the remuneration would then serve to prevent the circumvention of the underlying purpose of the proposed clawback provisions.

Whereas section $10 \mathrm{D}$ of the SEC Act is triggered by a financial restatement, the draft Bill does not require a financial restatement. The requirement to disclose under the Bill is triggered when a listed company

93 See $\mathrm{s} 9$ of Schedule 1 of the of the Corporations Legislation Amendment (Remuneration Disclosures and Other Measures) Bill 2012.

94 lbid.

95 S 250R(2) read with S $250 \mathrm{~V}$ of the Corporations Act 2001. For a detailed analysis of the two-strike rule under the Corporations Act 2001, see Kovačević 2012 23(2) The Economic and Labour Relations Review 103-106; Luiz 201325 SA Merc LJ 273-278.

96 Whether executive or otherwise. 
becomes aware of a material misstatement or omission in its financial statements.

However, under both section 10D of the SEC and the draft Bill the clawback is triggered by financial metrics, that is, material misstatements in the financial statements and there is no provision for other potential triggers. This may be criticised on the ground that it restricts the circumstances in which erroneously awarded remuneration may be recovered since companies may use non-financial metrics to determine performance-based remuneration.

\section{ASX Corporate Governance Principles and Recommendations}

In response to the concerns that the draft Bill was intended to address, the ASX Corporate Governance Council ${ }^{98}$ issued a draft of the third edition of the ASX Corporate Governance Principles and Recommendations in August $2013^{99}$ which contained a proposal that listed companies should adopt clawback policies. ${ }^{100}$ According to Recommendation 8.3 of the Draft Principles and Recommendations, a listed entity should:

"(a) have a clawback policy which sets out the circumstances in which the entity can clawback performance-based remuneration from its senior executives;

(b) disclose that policy or a summary of it; and

(c) disclose at the end of each reporting period:

(1) whether any performance-based remuneration has been clawed back in accordance with the policy during the reporting period; and

(2) where performance-based remuneration should have been clawed back in accordance with the policy but was not, the reasons for this."

Although the Council has not yet adopted the above recommendation, it signifies the Council's approach that clawbacks should be regulated within the framework of the Principles and Recommendations rather than in legislation. ${ }^{101}$ The recommendation reiterates the "if not, why not" mechanism underpinning the principles-based approach as opposed to a "one-size-fits-all" legislative approach. Under this approach, companies are not compelled to comply with the recommendations. A company is at liberty, subject to providing an explanation why to disregard the recommendation if the recommendation does not suit its specific circumstances. In addition, the Draft Principles and Recommendations have not prescribed the

\footnotetext{
Fried and Shilon 2011 36(4) The Journal of Corporation Law 748-749.

Hereinafter "the Council".

Hereinafter "the Draft Principles and Recommendations".

100 See ASX Corporate Governance Council "Review of the Corporate Governance Principles and Recommendations Public Consultation" 2013 http://www.asx.com.au/documents/asxcompliance/cgc-3rd-edition-consultation-paper.pdf (accessed 2016-10-01) 22. See also ASX Corporate Governance Council "Corporate Governance Principles and Recommendations Consultation Draft" 2013 http://www.asx.com.au/documents/public-con sultations/draft-cgc-3rd-edition.pdf (accessed 2016-10-01) 32.

101 ASX Corporate Governance Council http://www.asx.com.au/documents/asx-compliance /cgc-3rd-edition-consultation-paper.pdf 22.
} 
circumstances under which the companies can clawback performancebased remuneration from the executives. This has been left to companies themselves to determine.

\section{CLAWBACKS IN THE EU}

\section{The non-binding principles-based approach}

According to a statement issued by the European Corporate Governance Forum ${ }^{102}$ during the global financial crisis, the substance of director remuneration should not be regulated in a mandatory way at EU level. ${ }^{103}$ It is for companies and their shareholders to determine what pay structure, and levels are appropriate for their directors in light of their particular circumstances and different practices. The Forum stated that general best practices are evolving to ensure that the remuneration policy promotes the medium and long-term interests of the company rather than the short-term, that appropriate consideration should be given to the effects of incentivebased pay on the risks of the company, that excessive remuneration is excluded and that as little scope as possible is given to manipulation.

The Forum believed that key elements of such best practices include clawbacks. The document stated as follows:

"To the extent possible under applicable employment laws and companies' legislation, the company should reserve the right, at the discretion of nonexecutive directors, to reclaim performance linked remuneration elements which were paid to or vested on executive directors on the basis of results that afterwards were found to have been significantly misstated because of wrongdoing or malpractice ('clawback')."

Further, the EC issued the 2009 Recommendations, which had to be implemented by the member states by the end of $2009 .^{105}$ The Recommendations deal with the remuneration of executives of companies with a listing in the EU. More importantly, section II, 3.4, recommends that contractual arrangements with executive or managing directors should include provisions that permit the company to reclaim variable components of remuneration that were awarded on the basis of data which subsequently proved to be manifestly misstated. ${ }^{106}$ It has been accepted that the 2009

102 Hereinafter "the Forum".

103 European Commission "Statement of the European Corporate Governance Forum on Director Remuneration" (2009) http://ec.europa.eu/internal_market/company/docs/ecgforum lecgf-remuneration_en.pdf (accessed 2016-10-01) 2.

104 Ibid.

105 See Commission of the European Communities Recommendation complementing Recommendations 2004/913/EC and 2005/162/EC as regards the regime for the remuneration of directors of listed companies $2009 \mathrm{http}: / /$ ec.europa.eu/internal market/ company/docs/directors-remun/directorspay_290409_en.pdf (accessed 2016-10-01).

106 The other key provisions of the Recommendations include s II, 3.4, which provides that the award of variable remuneration should be subject to predetermined and measurable performance criteria and that performance criteria should promote long-term sustainability of the company and include relevant non-financial criteria. In terms of s II, 3.1, it should be possible for the company to withhold variable pay when performance criteria are not met. 
Recommendations are hard to argue with, even though they signify a significant tightening of the approach of the EC. ${ }^{107}$

Notably, the EC clawback recommendation does not require the presence of misconduct on the part of the company or the executives. The company should reclaim variable remuneration. Further, the EC clawback does not appear to be limited to only overpaid remuneration arising from misstated financial information, but would also apply to overpaid remuneration arising from errors in other metrics. The recommendation is, however, silent on the period during which the clawback should apply.

The EC clawback recommendation may be criticised on the ground that it is only limited to executive and managing directors. Moreover, the EU Recommendations are not binding. Member states have thus implemented the clawback recommendation as best practice under the codes of good governance as opposed to prescriptive legislative provisions.

In the UK, for example, clawbacks have been implemented via the nonbinding recommendations of the 2014 UK Corporate Governance Code, ${ }^{108}$ formerly the Combined Code on Corporate Governance. ${ }^{109}$ The UK Code recommends that performance-related remuneration schemes for executive directors should include provisions that would enable the company to recover sums paid or withhold the payment of any sum and specify the circumstances in which it would be appropriate to do so. ${ }^{10}$

Although the UK Code provides for the adoption of clawback policies, there are no binding legal requirements in this regard. ${ }^{111}$ Further, it is left to the discretion of company boards to determine the circumstances in which

107 Ferarini, Moloney and Ungureanu "Executive remuneration in crisis: a critical assessment of reforms in Europe" 2010 10(1) Journal of Corporate Law Studies 73116.

108 Financial Reporting Council "The UK Corporate Governance Code" 2014 D1.1.1 2014 https://www.frc.org.uk/Our-Work/Publications/Corporate-Governance/UK-CorporateGovernance-Code-2014.pdf (accessed 2016-10-01). Hereinafter "the UK Code".

109 Notably, in a referendum held in June $201651.9 \%$ of the UK's citizens voted in favour of the UK's withdrawal from the EU. However, the UK has not yet invoked the process set out in Article 50 of the Treaty on European Union for the formal withdrawal of a country from the EU. This means that the UK still remains a member of the EU until it invokes Article 50. The issue of clawbacks in the UK was first highlighted by the House of Commons Treasury Committee ("the Committee") in its ninth report of session 2008-2009. The Committee had concluded that the use of mechanisms such as the clawing back of bonus payments from senior and board level staff should be encouraged to align the interests of senior staff more closely with those of shareholders. The Committee called for a more widespread use of such mechanisms particularly within the financial sector as this would, in the Committees opinion; help discourage excessive risk-taking and short-termism. See House of Commons Treasury Committee "Banking Crisis: reforming corporate governance and pay in the City" (Ninth Report of Session 2008-09) 2009 http://www.publications.parliament.uk/pa/cm 200809/cmselect/cmtreasy/519/519.pdf (accessed 2016-10-01) 24.

110 Financial Reporting Council https://www.frc.org.uk/Our-Work/Publications/Corporate-Gover nance/UK-Corporate-Governance-Code-2014.pdf. The Code further recommends that remuneration incentives for executive directors should be compatible with risk policies and systems. See Schedule A to the UK Code.

111 The UK Code operates on a principles-based "comply or explain" basis, allowing companies the flexibility to disregard its recommendations in order to suit their individual circumstances on condition that the reasons for non-compliance should be explained to shareholders. See Financial Reporting Council https://www.frc.org.uk/Our-Work/Publications/Corporate-Gover nance/UK-Corporate-Governance-Code-2014.pdf 4. 
clawbacks would apply. This marks a sharp difference with the USA and the Netherlands (discussed below) where such policies are mandated by legislation.

It has been observed that clawbacks may raise considerable challenges that will need to be carefully considered in many countries within the EU. ${ }^{112}$ For example, requiring executives to pay back the remuneration that has already been paid could potentially breach the existing labour laws in some EU countries like France and Germany. ${ }^{113}$ The tax implications of the clawback will also need to be considered and clarified across the EU jurisdictions. ${ }^{114}$

\section{Mandated clawbacks in the Netherlands}

The Netherlands has passed legislation which makes it possible for open corporations (public limited companies), whether listed or not, to clawback directors' bonuses if they have been paid based on incorrect information. Article 2:135(8) of the Dutch Civil Code provides that the company:

"[l]s entitled to recover a bonus in full or in part to the extent that payment thereof has been made on the basis of incorrect information about the realization of the underlying goals or about the circumstances from which the entitlement to the bonus was made dependant.

Every public company has thus been given the power to seek recovery of the erroneously awarded bonuses. The recovery claim may also be filed in the name of the company by the supervisory board (in the case of a two-tier board), the non-executive directors of a one-tier board, or by a special representative appointed by the general meeting of shareholders for this purpose. ${ }^{116}$

Unlike the equivalent provisions in the USA and the draft Bill in Australia which require a material misstatement in the company's financial statements, article 2:135(8) of the Dutch Civil Code is not prescriptive of the potential triggers of the clawback and does not narrowly confine the clawback to situations where there are financial misstatements. On the contrary, the clawback will be possible in situations where incorrect information about the realisation of the underlying goals or about the circumstances on which the entitlement to the bonus was made dependant. Arguably, such situations may include but are not limited to, misstatements

112 See eg, Freshfields Bruckhaus Deringer "Cross-border remuneration issues for financial services firms" $2010 \mathrm{http}: / /$ www.freshfields.com/uploadedFiles/SiteWide/Knowledge/Crossborder\%20remuneration\%20issues\%20for\%20financial\%20services\%20firms.pdf (accessed 2016-10-01) 2-4.

113 lbid.

114 Ibid.

115 Article 2:135(8) of the Dutch Civil Code http://www.dutchcivillaw.com/civilcodebook022.htm (accessed 2016-10-07). In terms of Article 2:135(6) "bonus" refers to non-fixed remuneration, the entitlement of which is made dependent in full or in part on the realisation of certain goals or the occurrence of certain circumstances. In addition to public companies, the clawback provisions have been extended to directors and the day-to-day policymakers of financial institutions. See Article 1:111 of the Financial Supervision Act.

116 Article 2:135(8) of the Dutch Civil Code. 
in the financial statements and mismeasurement of other performance criteria. This could be a realisation on the part of the Dutch legislature that remuneration incentives may be determined not only in the light of financial performance metrics but also in the light of non-financial performance metrics like risk management and other circumstances significant to the company as well.

In contrast to the SEC Act in the USA and the draft Bill in Australia, article 2:135(8) of the Dutch Civil Code does not specify the period during which the clawback should apply. This is similar to the approach under the EC Recommendation and the UK Combined Code, which are also silent on how far back the clawback would apply. Due to the presumed reluctance of directors to actively seek recovery of overpaid remuneration from current or former directors and executives, article 2:135(8) gives the supervisory board, the non-executive directors or a special representative appointed by the general meeting the power to file a clawback claim on behalf of the company.

The clawback under article 2:135(8) may, however, be criticised on the ground that it only applies to directors and does not apply to certain key executives of public companies. Furthermore, the provision does not require the company to recover unearned or overpaid bonuses. It simply provides that the company is entitled to recover such bonuses. It, therefore, gives the board an unfettered discretion whether to clawback the bonuses.

\section{CLAWBACK POLICIES VOLUNTARILY ADOPTED BY COMPANIES}

Companies in various jurisdictions have voluntarily adopted clawback policies and specified the circumstances in which overpaid remuneration incentives will be clawed back. ${ }^{117}$ These policies are, however, unlikely to be effective in addressing the problem of excess incentives since they may not be enforceable. For instance, studies conducted in the USA revealed that before the enactment of Dodd-Frank the majority of the S\&P 500 companies did not adopt robust clawback policies requiring the companies to recover overpaid remuneration from the executives. ${ }^{118}$ The policies that existed simply gave the directors the discretion to recover overpaid remuneration from executives. ${ }^{119}$ It is, however, difficult to rely on directors to voluntarily recoup overpaid remuneration from fellow directors and from the executives. This is so because the directors will presumably be reluctant to actively seek repayment of overpaid remuneration form other directors or former directors and executives due to certain social, economic and psychological considerations. ${ }^{120}$ Such factors include considerations of loyalty amongst the directors and executives concerned as well as the desire to maintain good relations with departing and departed directors or executives. ${ }^{121}$

\footnotetext{
117 Australian Government http://archive.treasury.gov.au/documents/1926/PDF/101220\%20 Clawback\%20of\%20executive\%20remuneration\%20-\%20Final\%20-\%20Approved.pdf 7 .

118 Fried and Shilon 2011 36(4) The Journal of Corporation Law 737.

119 Ibid.

120 Fried and Shilon 2011 36(4) The Journal of Corporation Law 739.

121 Fried and Shilon 2011 36(4) The Journal of Corporation Law 732-735.
} 


\section{A SUGGESTED APPROACH FOR SOUTH AFRICA}

The above discussion has examined the need for the clawing back of overpaid remuneration, the rationale for clawback reforms as well as the approaches adopted in selected international jurisdictions that have implemented clawback reforms. It is, however, clear from the discussion above that clawbacks pose a number of practical problems in implementation, which need to be carefully thought out. The author considers here whether a remuneration clawback would be appropriate in South Africa and, if so, how it could be implemented, based on the lessons learnt from an examination of the approaches adopted by its international counterparts.

\section{Should clawbacks be introduced in South Africa?}

In South Africa, the remuneration of company directors and prescribed officers is regulated under the Companies Act 71 of 2008 as well as under market-based regulatory instruments such as the King IV Report on Governance for South Africa $2016^{122}$ and the listings requirements of the Johannesburg Stock Exchange. ${ }^{123}$ Although the Companies Act 71 of 2008 contains provisions related to the disclosure of remuneration of directors and prescribed officers, it does not provide for the recovery or clawing back of overstated incentives or other remuneration. Similarly, the JSE Listings Requirements are silent on the issue of remuneration clawback. In a positive step, the King IV Report, which came into effect on 1 April 2017, has introduced a new recommendation that companies should adopt remuneration policies which should set out inter alia "the provisions (if any) for pre-vesting forfeiture (malus) and post-vesting forfeiture (clawback) of remuneration. $^{124}$ Unfortunately, the non-binding principles of the King IV Report are silent on the circumstances in which it would be appropriate for companies to clawback the remuneration. The King IV Report has also left the adoption of clawback provisions to the discretion of companies. The absence of a requirement for the clawback of remuneration in South Africa would, therefore, mean that shareholders would have to institute legal proceedings in order to recover the erroneously awarded amounts. As already pointed out, clawback litigation may be protracted and costly for shareholders. $^{125}$

Furthermore, South African companies are increasingly adopting the US, UK and Australian type remuneration structures with a strong emphasis on the payment of performance-based incentives. ${ }^{126}$ A recent study conducted by Massie, Collier and Crotty has revealed that in most of South Africa's big companies, bonuses and share-based incentives constitute a substantial portion of the remuneration packages awarded to executives. ${ }^{127}$ The

\footnotetext{
122 Hereinafter "the King IV Report".

23 Hereinafter "JSE Listings Requirements".

24 See the King IV Report 65 par 30e.

125 Fried and Shilon 2011 36(4) The Journal of Corporation Law 731.

126 Massie et al Executive Salaries in South Africa: Who should have a Say on Pay? 31-35.

127 Ibid.
} 
developments that preceded clawback reforms in the US, EU and Australia have already highlighted the danger of incentive-based remuneration, including the remuneration structures that are designed to encourage shortterm behaviour to the potential detriment of the long-term value of companies.

In addition, as discussed above, mismeasurement of performance metrics for determining incentive-based remuneration will potentially undermine the pay-performance link and its attendant advantages. ${ }^{128}$ Therefore, there is a need for appropriate regulation in order to address the dangers associated with the prevalent remuneration structures and to ensure that performance incentives are properly aligned with the company's long-term value. Introducing clawbacks would be one way of achieving these imperatives. In my view, the rationale for the clawback of overpaid incentive-based remuneration in the international jurisdictions is equally relevant to the South African market.

\section{The form of the clawback}

It is clear from the discussion above that there are four ways in which a clawback may be implemented. The first is through legislation. The second is through the rules of stock exchanges. The third is through the non-binding codes of best practice. The fourth is through policies voluntarily adopted by companies. Therefore, South Africa has an option to introduce the clawbacks via the Companies Act 71 of 2008, or the JSE Listings Requirements, or the King Reports, or voluntary policies adopted by companies themselves. If the clawback is regulated through the JSE Listings Requirements, it would only apply to companies whose securities are listed on the JSE. The major drawback of introducing the clawback through the recommendations of the King Reports such as the King IV Report is that as a market-based code of best practice the principles of the King IV Report are not binding on non-listed companies. The implementation of a clawback recommendation under the King IV Report would, therefore, predominantly depend on the directors' discretion yet, as discussed above, the directors would generally be reluctant to actively seek recovery of overpaid remuneration from fellow directors and executives. ${ }^{129}$ Similarly, the effectiveness of voluntary clawback policies adopted by companies is questionable. The major flaws of such policies include that they may not be sufficiently robust and that there is no obligation on all companies to have these policies in place. ${ }^{130}$

The author, therefore, suggests that the clawback should be enshrined in the Companies Act 71 of 2008. This is because the provisions of the Companies Act 71 of 2008 are mandatory and the provision could be framed in such a manner that it applies to a wide category of companies (as discussed below). This would be in line with the approach in the USA and the Netherlands as well as that proposed in Australia, of implementing the

128 See par 2 for a discussion of the policy justifications for the introduction of remuneration clawbacks.

129 See Fried and Shilon 2011 36(4) The Journal of Corporation Law 739.

130 See the discussion of clawback policies voluntarily adopted by companies in par 6 above. 
clawback via legislation. I further propose that the introduction of a clawback in the Companies Act 71 of 2008 should not bar the regulation of clawbacks through the JSE Listings Requirements and the King IV Report provided that these latter methods do not conflict with the statutory provision.

\section{The companies that should be subject to the clawback}

The approaches adopted by the international jurisdictions discussed above appear to be in support of the view that there should generally be a widespread use of clawbacks. For instance, the clawback under section 10D of the SEC Act applies to all companies listed in the USA regardless of size and of the categories of securities issued by the company. The clawback provision proposed in Australia would also apply to all companies listed in Australia and no category of the company has been exempted from complying with the proposed requirements. The Netherlands goes even further than Australia and the USA, as the clawback under article 2:135(8) of the Dutch Civil Code applies to all public companies, whether listed or not. It is submitted that the developments are a manifestation of a realisation that the policy objectives of clawing back overpaid remuneration (discussed above) are relevant for a wide category of companies, including those which could be regarded as relatively small companies. However, it has been pointed out that regulators should be careful not to unduly burden smaller companies with compliance issues relating to remuneration clawbacks as well as companies that are unlikely to derive any economic benefits from the clawback requirements. ${ }^{13}$

The author, therefore, proposes that companies in South Africa that should be subject to the clawback provision are companies that are currently required to disclose information on the remuneration of directors and prescribed officers in their annual financial statements. These are companies that are required in terms of the Companies Act, 2008, to have their annual financial statements audited, ${ }^{132}$ namely public companies, stateowned companies as well as any other profit or non-profit company, the annual financial statements of which must be audited if so required by the regulations made by the Minister in terms of section 30(7), taking into account whether it is desirable in the public interest, having regard to the economic or social significance of the company, as indicated by any relevant factors, including its annual turnover, the size of its workforce, or the nature and extent of its activities. ${ }^{133}$ In my view, these are relatively big companies

See the discussion under par 341 above.

S 30(4) of the Companies Act 71 of 2008.

$133 \mathrm{~S} \mathrm{30}(2)$ (b)(i) of the Companies Act 71 of 2008. The latter category of companies would include any profit or non-profit company if, in the ordinary course of its primary activities, it holds assets in a fiduciary capacity for persons who are not related to the company and the aggregate value of such assets held at any time during the financial year exceeds R5 million; any non-profit company if (i) it was incorporated directly or indirectly by the state, an organ of state, a state-owned company, an international entity, a foreign state entity or a foreign company, or (ii) it was incorporated primarily to perform a statutory or regulatory function in terms of any legislation, or to carry out a public function at the direct or indirect initiation or direction of an organ of the state, a state-owned company, an international entity, or a foreign state entity, or for a purpose ancillary to any such function; and any other 
in terms of their social significance and the stakeholders of these companies, including the South African market, would benefit from the introduction of a clawback requirement.

\section{Persons to whom the clawback should apply}

The approach followed under SOX, the EU Recommendations, the UK Code and the Dutch Civil Code may be criticised for entitling the company to recover overpaid remuneration from only a very limited category of individuals. ${ }^{134}$ It excludes a number of officers who play an influential role in the management of companies from the ambit of the clawback provisions and would restrict the effectiveness of the clawback provisions in practice. Accordingly, I suggest that the clawback provision in South Africa should apply to directors and prescribed officers of the company, including former directors and prescribed officers of the company who would have received overpaid remuneration in the period over which the clawback applied. This would be consistent with section 10D of the SEC Act that has extended the application of the clawback provision to any current or former executive officer of the company (as defined) who received incentive-based compensation during the preceding three-year period. It would also be consistent with the clawback proposed in Australia by the draft Bill that would apply to all key management personnel (as defined) of all listed companies. The difference would be that the draft Bill is silent on whether the clawback would apply to former key management personnel as well.

In the author's view, concerns relating to the practicality of applying the clawback provision to South African prescribed officers could be ameliorated by giving the board of directors the necessary, albeit limited, discretion to invoke the clawback provision. Such discretion should be subject to necessary safeguards such as the requirement that the board genuinely believes that the recovery would not be in the best interests of the company and appropriate disclosure requirements. In addition, applying the clawback to current and former directors and prescribed officers would be in line with the current section 30(4) of the Companies Act 71 of 2008 which provides for the disclosure of information in relation to directors' and prescribed officers' remuneration, including that of former directors and prescribed officers. The purpose of extending the clawback to former directors and prescribed officers would be to prevent the directors and prescribed officers from circumventing the clawback by simply resigning.

\section{Potential triggers of the clawback}

It is recommended that, in order to avoid undesirable legislative rigidity, South Africa should adopt the approach similar to that under article 2:135(8) of the Dutch Civil Code, which is not prescriptive of the potential triggers of

company whose public interest score in that financial year is 350 or more, or is at least 100 , if its annual financial statements were internally compiled.

134 For instance, the SOX clawback applies to the CEO and CFO of the company only and, as discussed above, the clawback under the EU Recommendations, the UK Code and the Dutch Civil Code applies to company directors only. 
the clawback. The Companies Act 71 of 2008 should, in this regard, contain a provision requiring companies to recover incentive-based remuneration to the extent that the awarding, vesting or payment of such remuneration has been made on the basis of incorrect information about the realisation of the underlying goals or about the circumstances from which the entitlement to the remuneration was made dependant. Such an approach would differ from that in the USA and that proposed for Australia where clawbacks are triggered only by financial misstatements.

Focusing solely on financial metrics would restrict the operation of clawbacks since companies may use a wide variety of metrics, events, or circumstances relevant to each company - including non-financial ones - to determine performance-based remuneration. Therefore, the reach of the clawback provisions should be broad enough to cover financial performance metrics, non-financial performance metrics, as well as other circumstances in order to be effective. This suggested approach would also be in line with section II, 3.4 of the EU Recommendation in terms of which, as discussed above, the clawback would be triggered by data, which subsequently proved to be manifestly misstated. The term "data" would presumably cover financial as well as non-financial information.

\section{Wrongdoing}

The author proposes that the existence of wrongdoing ${ }^{135}$ should be disregarded when considering whether to apply the clawback. This would be in line with the clawbacks under section 10D of the SEC Act, the proposed SEC Rule 10D-1, the EESA, the EU Clawback Recommendation, the UK Code, the Dutch Civil Code, as well as the draft Bill and the Draft Principles and Recommendations in Australia. In terms of all the above regulatory instruments, the clawbacks could be invoked regardless of whether or not there was wrongdoing on the part of the company or the individuals concerned. It is evident from these regulatory instruments that the clawing back of overpaid remuneration should be regarded an equitable remedy against unjust enrichment. A requirement for wrongdoing would, in my view, be superfluous as overpaid remuneration may result even in the absence of wrongdoing. The requirement for wrongdoing could, as already pointed out, potentially lead to costly litigation, and would undermine the effectiveness of the clawback provision in promoting accountability and preventing unjust enrichment. ${ }^{136}$

\section{The clawback period}

The legislation should specify the time period over which the clawback should be applied in order to promote certainty and enforceability. As discussed above, in the USA, the Dodd-Frank clawback prescribes a "look back" period of three preceding fiscal years from the date the company is required to prepare an accounting restatement and this is longer than the

135 Intention or misconduct.

136 See the critique of the misconduct requirement in the discussion of the SOX clawback in par 31 above. 
twelve-month period prescribed in the earlier SOX. A similar approach has been proposed in Australia. Later regulatory instruments such as the UK Code and the Dutch Civil Code are silent on how far back the clawback should apply. Although the clawback period should ideally be extended enough to cover all possible overpaid incentives in order to be effective, ${ }^{137}$ an extraordinarily long or an unspecified period may raise difficulties with enforcement. There will likely be huge practical challenges in seeking recovery, as noted by the Australian government, where longer periods of say twenty years have lapsed since the occurrence of the triggering event. ${ }^{138}$

\section{The responsibility for applying the clawback}

The author recommends that the Companies Act 71 of 2008 should require the company to clawback the erroneously awarded remuneration from its present or former directors or prescribed officers. This would help remove the burden on shareholders to litigate clawback claims. The developments in the USA have also shown that placing the onus on bodies such as stock exchanges would not lead to optimum outcomes. ${ }^{139}$

In order to avoid the rigidity often associated with legislation evident from the USA's approach under section 10D of the SEC Act, an approach akin to the "if not, why not" approach proposed for Australia be adopted in South Africa. Under this approach, the company should be required to seek recovery of the erroneously awarded remuneration except where the company provides an explanation as to why recovery could not be sought. The Companies Act 71 of 2008 should, in this regard, provide for limited circumstances in which a company would be permitted not to seek recovery. I suggest, in line with Rule 10-D in the USA, that the Companies Act 71 of 2008 should permit a company not to seek recovery where recovery would be impracticable or where the recovery costs would be greater than the recoverable amount. Further, the board must genuinely believe that it is in the best interests of the company not to seek recovery.

The approach suggested would arguably prevent the circumvention of the clawback provisions through limiting the board's discretion whether to seek recovery of the erroneously awarded remuneration. At the same time, it would allow for the flexibility needed to cater for a situation where seeking

137 Notably, in the UK the Financial Conduct Authority (FCA) has recently introduced rules for the clawback of variable remuneration paid to all material risk takers for a period of 7 years from date of award. Further the FCA and Prudential Regulation Authority (PRA) has introduced a rule to extend the 7 year clawback period to 10 years for senior managers. See Bank of England Prudential Regulation Authority "Strengthening the alignment of risk and reward: new remuneration rules" $2015 \mathrm{http}: / / \mathrm{www}$. bankofengland.co.uk/pra/Pages/ publications/ps/2015/ps1215.aspx (accessed 2016-10-04). These rules came into force on 1 January 2016 and are aimed at discouraging irresponsible risk-taking and short-termism and to encourage more effective risk management in the financial services.

138 Australian Government http://archive.treasury.gov.au/documents/1926/PDF/101220\%20 Clawback\%20of\%20executive\%20remuneration\%20-\%20Final\%20-\%20Approved.pdf 20.

139 See the discussion of clawbacks under SOX the EESA and Dodd-Frank in par 3.1, 3.2 and 3.3 above. It has been noted that the clawback provisions in the EESA and Dodd-Frank may be invoked by the company and that this is an improvement when compared to the earlier SOX clawback provision that may only be invoked by the SEC. See also Fried and Shilon 2011 36(4) The Journal of Corporation Law 731. 
recovery would not be practical, would not lead to any economic benefits accruing to the company and would genuinely not be in the interests of the company.

\section{The determination of the clawback amount}

The board should determine the recoverable amount within a reasonable period following the event that triggered the clawback. However, the Companies Act 71 of 2008 should provide guidance on how the amount is to be determined in order to assist company boards in this regard. The tax implications of the clawback should also be clarified in the legislation. Once the board has determined the recoverable amount, the company should be required to clawback the remuneration from the individuals concerned within a reasonable period of time.

\section{Indemnification of directors}

In line with Rule 10D-1 in the USA, the Companies Act 71 of 2008 should not allow companies to indemnify - directly or indirectly - directors and executives against the recovery of the erroneously awarded remuneration. Providing indemnity to directors would enable directors and executives to retain the unearned or overpaid remuneration and would negate the underlying purposes of the clawback provision discussed above.

\section{Disclosure}

It is recommended that the Companies Act 71 of 2008 should require companies to disclose their clawback policies. Companies should also be required to disclose information in relation to compliance with the clawback policies. This would be in line with Rule 10D-1 in the USA and the draft Bill in Australia. Requiring companies to disclose their clawback policies and how the policies have been implemented would promote greater transparency and also exert pressure on companies to comply with the clawback requirements.

\section{CONCLUSION}

South Africa's remuneration practice follows UK, USA and Australian practice that has a strong emphasis on the payment of bonuses and the use of share-based incentives. The corporate scandals and the global financial crisis of 2008-2009 have highlighted the danger of executives managing companies in pursuit of short-term performance-based incentives at the expense of long-term value. The clawing back of incentive-based remuneration paid to certain directors and executives seeks to promote responsible management of companies, long-term sustainability of companies, transparency, and accountability for inappropriate behaviour. It also seeks to prevent the manipulation of data, the diversion of corporate funds and unjust enrichment. 
The article has examined the clawback reforms in the USA, Australia, the UK, the EU and the Netherlands. It has identified and analysed the potential benefits and shortcomings of the regulatory reforms in each jurisdiction. It has paid particular focus on the form of the clawback; the categories of companies that should be subject to the clawback; the range of persons to whom the clawback should apply; the potential triggers of the clawback; the time period over which the clawback should apply; the amount recoverable; the responsibility for applying the clawback; indemnification of directors as well as disclosure of the clawback policy and details of implementation. It is clear from the discussion above that clawbacks posing a number of practical problems in implementation, which need to be carefully thought out.

The South African regulatory framework in relation to the director and executive remuneration does not provide for remuneration clawbacks. The absence of a requirement for the clawback of remuneration means that shareholders will have to embark on costly legal proceedings in order to recover the amounts erroneously awarded. South Africa's regulatory framework in relation to the director and executive remuneration should be strengthened and modernised in order to keep pace with changing regulatory challenges. It is, therefore, recommended that South Africa should adopt and regulate the clawback of incentive-based remuneration in the Companies Act, 2008. The introduction of a clawback in this Act should, however, not bar the regulation of clawbacks through the JSE Listings Requirements and the King Reports provided that these latter methods do not conflict with the statutory provision. A robust framework for the regulation of clawbacks in a manner that allows for greater transparency and accountability, as recommended above, would be in line with the objectives of the Companies Act 71 of 2008 as set out in section 7(b)(iii) and (j). 